\title{
First genetically confirmed Eastern Subalpine Warbler Sylvia cantillans for Sweden
}

\author{
Första genetiskt bekräftade östlig rödstrupig sångare Sylvia cantillans $i$ Sverige
}

STEPHEN MENZIE, MARCEL GIL-VELASCO \& J. MARTIN COLLINSON

Abstract

\begin{abstract}
An adult male Sylvia cantillans sensu lato was ringed at Falsterbo Bird Observatory on 19 May 2013. Plumage, biometry and calls suggested an Eastern Subalpine Warbler $S$. cantillans sensu stricto, recently given species status by the Swedish taxonomy committee. As of 2012, there are seventy accepted Subalpine Warbler records in Sweden but none has been assigned to any of the three new splits: Western (inornata), Eastern (cantillans) or Moltoni's (subalpina) Warbler. A genetic analysis of the Falsterbo bird showed it to be Sylvia cantillans albistriata, the first of this taxon to be unequivocally identified in Sweden.
\end{abstract}

Stephen Menzie, 24 Linkside Road, Liverpool L25 9NY, UK; stephen.menzie@gmail.com

Marcel Gil-Velasco, Dalt 1, 3r 2 a 08980 Sant Feliu de Llobregat, Barcelona, Spain; marcelgilvelasco@gmail. com

J. Martin Collinson, University of Aberdeen, School of Medical Sciences, Institute of Medical Sciences, Foresterhill, Aberdeen AB25 2ZD, UK; m.collinson@abdn. ac.uk

Received 5 November 2014, Accepted 29 January 2015, Editor: D. Hasselquist

\section{Introduction}

On 19th May 2013, during daily standardised ringing at Falsterbo Bird Observatory, Skåne, Sweden, MGV extracted a male subalpine warbler Sylvia cantillans sensu lato from a mist-net north of Falsterbo Lighthouse garden. Plumage characteristics, with a deep vinous-red breast extending as far as the fore-flanks and contrasting with the white rear-flanks and belly, and a broad white moustache stripe (Figure 1), immediately suggested that the bird was of an Eastern Subalpine Warbler $S$. cantillans sensu stricto (see text box for a summary of nomenclature and taxonomy), recently afforded specific status by Svensson (2013a). Additionally, the tail pattern, with a deep white wedge at the tip of the second-outermost tail feather (R5) and a smaller white wedge at the tip of R4 (Figure 2), supported the identification as Eastern (Svensson 2013a, Svensson 2013b).

\section{Biometrics}

Male wing lengths are given by Cramp \& Brooks (1992) for Western Subalpine Warbler and Eastern Subalpine Warbler as $58-63 \mathrm{~mm}$ and $58-67 \mathrm{~mm}$ respectively. The Falsterbo bird showed a wing length of $65.0 \mathrm{~mm}$, maximum chord (Svensson 1992) measured to nearest $0.5 \mathrm{~mm}$, further supporting the identification as Eastern Subalpine Warbler.

\section{Ageing}

Juvenile Eastern Subalpine Warbler undergo a partial post-juvenile moult while adults undergo a complete post-breeding moult, both prior to autumn migration. Prior to spring migration, both age classes undergo a partial pre-breeding moult (Shirihai et al. 2001). The species can prove tricky to age in spring/summer, especially since some individuals can become very worn and there can be several generations of feather in the wing. The Falsterbo bird showed adult-type tail feathers. However, caution is advised when ageing bird with adult-type tail feather since they are, especially so it seems in Sylvia warblers, prone to loss and regrowth; lost and subsequently regrown feathers will be adulttype regardless of the age of the bird. The wing was in overall rather good condition with, for a subalpine warbler in spring, relatively little wear (pers obs). The secondaries and inner primaries were broad and dark. Both the degree of wear and colour/shape of the feathers suggested an adult $(3+$ cy) 


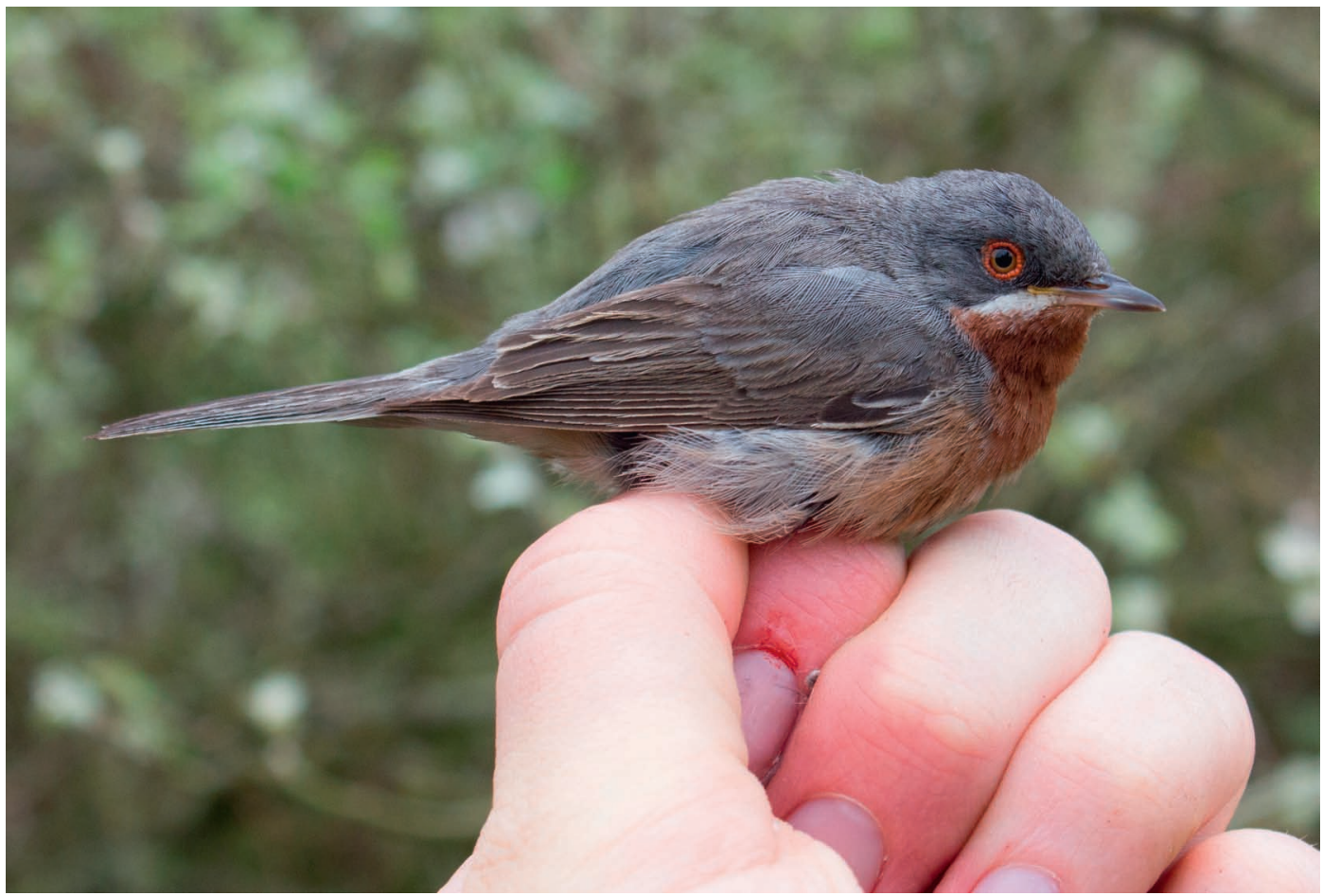

Figure 1. Eastern Subalpine Warbler Sylvia cantillans albistriata, Falsterbo Bird Observatory, Sweden, 19/05/2013 (Stephen Menzie).

Nomenclature and taxonomy used in this paper follow Svensson (2013a). The three taxa as a whole are referred to as Subalpine Warbler Sylvia cantillans sensu lato.

\section{Western Subalpine Warbler Sylvia inornata} Tschusi, 1906

Sylvia inornata inornata Tschusi, 1906. Northwest Africa.

Sylvia inornata iberiae Svensson, 2013 Iberia, southern France, extreme north-west Italy.

\section{Eastern Subalpine Warbler Sylvia cantillans (Pallas, 1764)}

Sylvia cantillans cantillans (Pallas, 1764). Central and south Italy except Sardinia.

Sylvia cantillans albistriata (C. L. Brehm, 1855). Trieste, Balkans, Greece, Bulgaria, western Turkey.

Moltoni's Warbler Sylvia subalpina Temminck, 1820

Monotypic. Mallorca, Cabrera, Corsica, Sardinia, north mainland Italy. bird. Assessment of the greater coverts confirmed this. On the right wing, GC10-6 (numbered ascendently) were pre-breeding (moulted early 2013) and GC5-1 were post-breeding (moulted autumn 2012). On the left wing (Figure 3.), GC5 was newer than the pre-breeding, presumably following accidental loss and regrowth. S9 on the right wing was also new, and partly grown, following presumed accidental loss. Pre-breeding moulted greater covers should be similar in both adult and second calendar-year (2cy), so these should not be considered when ageing the bird. However, the oldest generation of feathers in the greater coverts - post-breeding in $3+$ cy or retained juvenile feathers in 2cy - display differences in colour pattern, texture and wear and thus can be used for ageing. In the Falsterbo bird, GC1-5 (the oldest feathers in the tract) were reasonably fresh and tipped grey, as expected for a $3+c y$ bird. In a 2 cy bird, retained juvenile greater coverts would be tipped brown and heavily worn. Rarely a first-year bird may moult all greater coverts during the post-juvenile moult (Shirihai et al. 2001), in which case all oldest generation greater coverts would be adult-like. However, the primary coverts, which are not moulted 


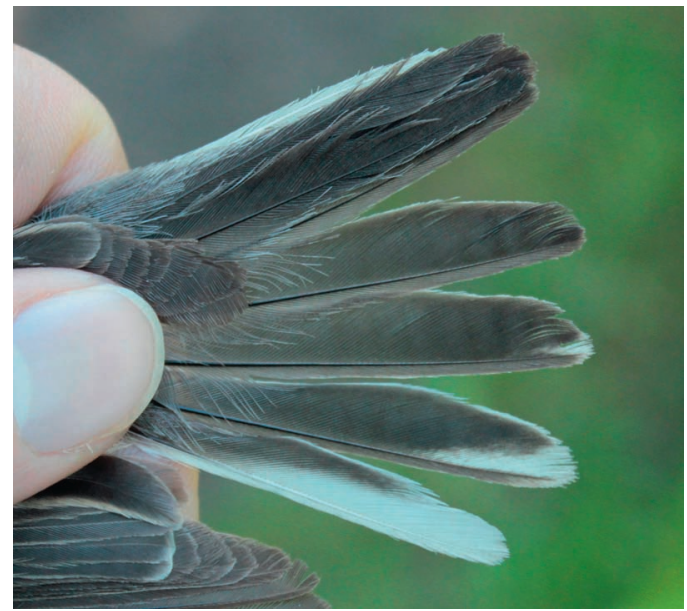

Figure 2. Eastern Subalpine Warbler Sylvia cantillans albistriata, Falsterbo Bird Observatory, Skåne, Sweden, 19/05/2013 (Stephen Menzie). See text for description of tail pattern.

during post-juvenile nor pre-breeding moult, were solid in texture, relatively broad and edged grey on the Falsterbo bird, as expected in an 3+cy bird but not matching the expected appearance for a $2 \mathrm{cy}$ bird (Shirihai et al. 2001; pers. obs.).

In conclusion, plumage and moult allows the bird to be aged as an adult ( $3+$ cy).

Additionally, the orange iris (merging to redorange around the outer edge) supported the ageing of the bird as 3+cy (Shirihai et al. 2001); in 2cy males, the iris is duller and often greener.

\section{Vocalisation}

On release, the bird was heard to call - a quiet trrt or double trrt-trrt; softer and more stuttering than the single harsh $t c k$ given by iberiae/inornata and quite different from the Wren-like rattle given by subalpina. Calls were sonogrammed using Raven Lite (http://www.birds.cornell.edu/brp/raven/

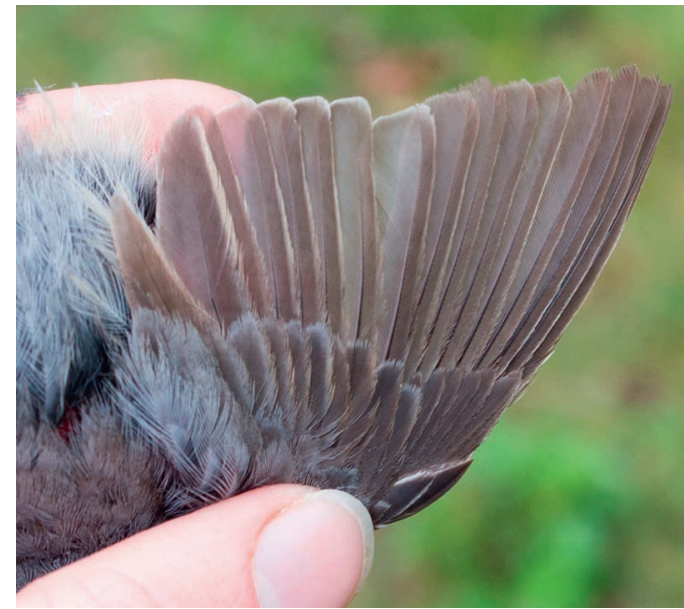

Figure 3. Eastern Subalpine Warbler Sylvia cantillans albistriata, Falsterbo, Sweden, 19/05/2013. See text for detailed explanation of moult pattern and ageing criteria.

RavenOverview.html). Sonograms of the call (Figure 4), recorded upon release, correspond well with those shown in Shirihai et al. (2001) for Eastern Subalpine Warbler with rather arched harmonics giving a 'broad' and 'open' structure to the call note. They display the expected differences when compared to the call notes of Western Subalpine Warbler (Figure 5), for which the harmonics of each call are strongly sloped downwards giving an overall rather dense and 'vertical' structure to each call note.

\section{Genetic analysis}

Feathers shed during the ringing process allowed for the extraction of enough genetic material to carry out genotypic analysis. Feather samples were used to isolate DNA using the QIAamp DNA Micro Kit (QIAGEN, UK) with addition of $0.1 \mathrm{M}$ dithiothreitol to the digestion mix and elution in

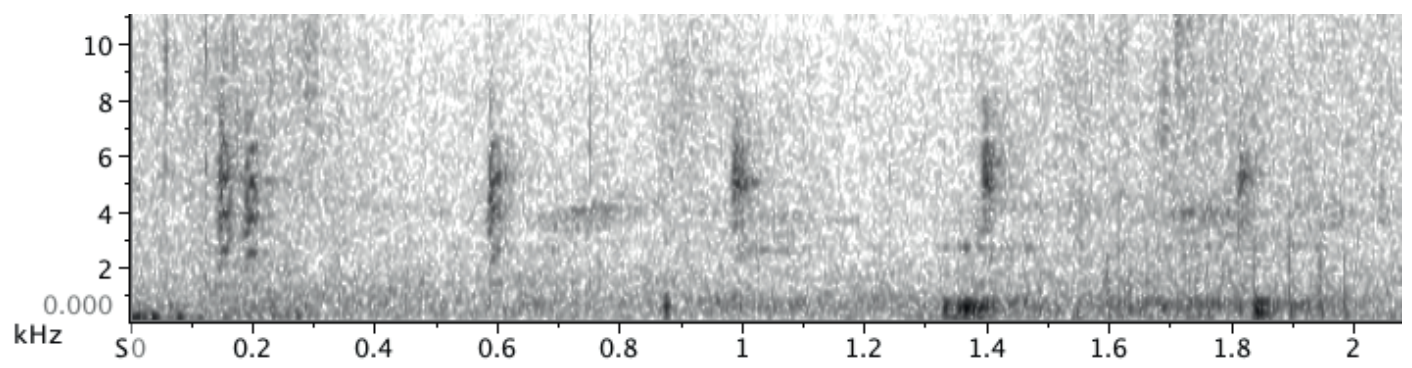

Figure 4. Eastern Subalpine Warbler Sylvia cantillans albistriata, calls upon release, Falsterbo Bird Observatory, Skåne, Sweden, 19/05/2013 (Stephen Menzie). Note the double call at the start of the sequence. The harmonics of each call note are arched in appearance giving the call a 'broad' and 'open' structure. 


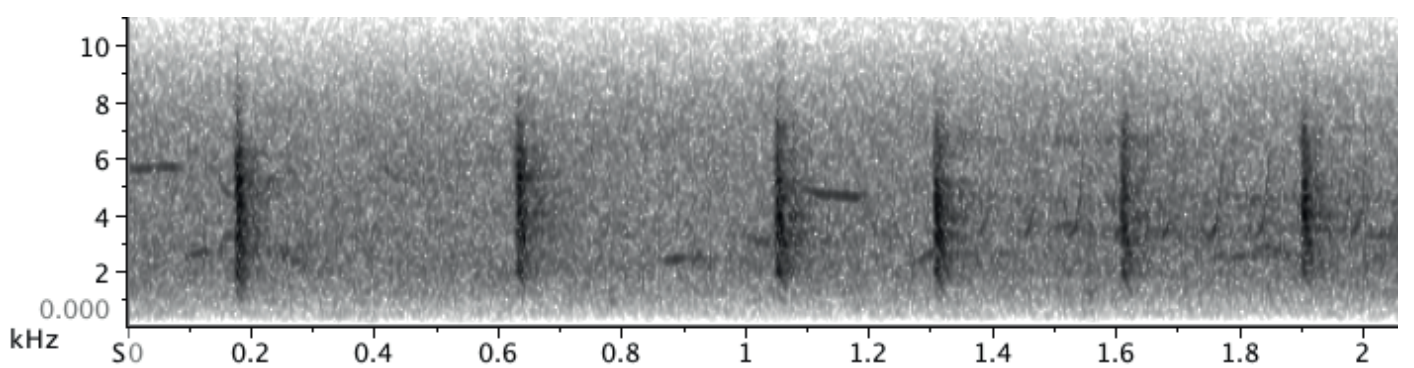

Figure 5. Western Subalpine Warbler Sylvia inornata iberiae, Aragon, Spain (Thijs Fijen). The harmonics of each call are strongly sloped downwards giving an overall rather dense and 'vertical' structure to each note, quite distinct from that of Eastern Subalpine Warbler.

$80 \mu \mathrm{l}$ of QIAGEN buffer AE. The mitochondrial cytochrome b (cytb) gene was amplified using the L14993 and H16065 primers according to protocols established by Helbig et al. (1995).

PCR products were separated by electrophoresis on a $1.5 \%$ agarose gel. The DNA from each gel fragment was then isolated using the QIAquick Gel Extraction Kit (QIAGEN, UK) according to the manufacturer's protocols. Gel-extracted PCR products were then diluted to $1 \mathrm{ng} / \mu \mathrm{l} / 100 \mathrm{bp}$ and sequenced by the Source BioScience LifeSciences (Cambridge) DNA sequencing service. 987 bp of unambiguous single-pass sequence were obtained using the L14993 primer, submitted to the EMBL Nucleotide database (Accession number LN650644), and compared with previously sequenced 'subalpine' warblers using nucleotide BLAST (http://blast.ncbi.nlm.nih.gov/Blast.cgi). $C y t b$ sequences of multiple individuals of all relevant taxa (except nominate $S$. inornata) have previously been deposited in the database. The BLAST search showed that the Falsterbo individual was unambiguously assignable to $S$. cantillans albistriata. It was $100 \%$ identical to Sylvia cantillans albistriata haplotype a2 previously identified by Brambilla et al. (2008) in a bird from Lesvos (Accession number EU760671) and 1-4 bp different from multiple other individuals of $S$. c. albistriata from Lesvos and Dalmatia. It was 12-20 bp different (98.8-98.0\% identity) compared with multiple individuals of nominate $S$. c. cantillans s.s. from southern Italy. All S. inornata sequences were at least $34 \mathrm{bp}$ different from the Falsterbo bird and all $S$. subalpina sequences were at least $41 \mathrm{bp}$ different, eliminating these two species from further consideration.

\section{Summary}

As of the 2012 Swedish Rarities Committee assessment, there were 70 accepted records of $S$. cantillans s.l. in Sweden (Björn Malmhagen \& Hans Larsson pers. comm. on behalf of Swedish Rarities Committee). All records are accepted as 'subalpine warbler', though a reassessment of accepted records may allow the acceptance of some individuals as iberiae/inornata, subalpine, or cantillans/ albistriata, treated as of 2014 as three species by the Swedish Taxonomic Committee following Svensson (2013a).

Plumage, morphometrics and call all suggest that the Falsterbo bird was Eastern Subalpine Warbler, with genetic analysis confirming its identification as $S$. cantillans albistriata. This individual is currently the only unequivocally identified individual of this taxon in Sweden.

The bird was seen throughout the day on 19th May, wandering as far as Nabben. The bird was not seen subsequently until 23rd May when, surprisingly, it was present again in the lighthouse garden.

\section{Acknowledgments}

With thanks to Sissel Sjöberg and Rachel Muheim, Lund University, for their cooperation with fieldwork. Björn Malmhagen and Hans Larsson provided details of subalpine warbler records on behalf of the Swedish Rarities Committee. Albin Enetjärn provided a Swedish summary of the text.

This is report number 289 from Falsterbo Bird Observatory. 


\section{References}

Brambilla, M., Vitulano, S., Spina, F., Baccetti, N., Gargallo, G., Fabbri, E., Guidali, F. \& Randi, E. 2008. A molecular phylogeny of the Sylvia cantillans complex: cryptic species within the Mediterranean basin. Molec. Phylogenet. Evol. 48:461-472.

Cramp, S. \& Brooks, D. J. (eds.) 1992. Handbook of the Birds of Europe, the Middle East and North Africa vol. VI. Oxford University Press, Oxford.

Helbig, A. J., Seibold, I., Martens, J. \& Wink, M. 1995. Genetic differentiation and phylogenetic relationships of Bonelli's Warbler Phylloscopus bonelli and Green Warbler P. nitidus. J. Avian Biol 26: 139-152.

Shirihai, H., Gargallo, G. \& Helbig, A. 2001. Sylvia Warblers. Christopher Helm, London.

Svensson, L. 1992. Identification Guide to European Passerines. Lars Svensson, Stockholm.

Svensson, L. 2013a. A taxonomic revision of the Subalpine Warbler Sylvia cantillans. Bulletin of the British Ornithologists' Club 113:240-248

Svensson, L. 2013b. Subalpine Warbler variation and taxonomy. British Birds 106:651-668.

\section{Sammanfattning}

En hane rödstrupig sångare Sylvia cantillans sensu lato fångades och ringmärktes vid Falsterbo Fågelstation den 19 maj 2013. Dräktegenskaper, stjärtmönster, biometri, vingformel och lockläte stödde identifieringen av fågeln som östlig rödstru- pig sångare Sylvia cantillans (se faktarutan för en sammanfattning av terminologi och taxonomi), vilken nyligen fått artstatus av Taxonomikommittén som följer Svensson (2013a). Fågeln blev åldersbestämd som en adult $(3 \mathrm{k}+)$, baserat på de större täckarna - den äldre generationen var av adult karaktär vilket visade att fågeln genomgått minst en komplett ruggning; hand/armpennor och stjärt relativt fräscha jämfört med vad som kan förväntas av en 2k-fågel; samt ögonfärgen - ljust orange/röd jämfört med en förväntad mattare färgad, grönaktig iris hos en $2 \mathrm{k}$-fågel.

Fram till 2012 fanns det 70 accepterade, men ej artbestämda, fynd av gruppen rödstrupig sångare i Sverige. Rödstrupig sångare behandlas från 2014 som tre arter av den svenska taxonomikommittén, där den östliga Sylvia cantillans behåller namnet rödstrupig sångare. Den svenska raritetskommittén håller för närvarande på med en genomgång för att utreda vilka av de svenska fynden som kan ges artstatus.

Genetiskt material som togs från Falsterbofågeln visade sig efter DNA-analys stämma överens med genetiken hos den östliga arten rödstrupig sångare S. cantillans albistriata. Fyndet blir därmed det första genetiskt bevisade av denna art i Sverige och fågeln är för närvarande den enda entydigt identifierade individen i detta taxon. 